\title{
$\mathrm{Al}$ 系および Fe 系アモルファス合金の結晶化過程
}

\author{
藤田廣志* 坪井猛文** 原田勝之什 \\ *近畿大学理工学稔合研究所 \\ **近畿大学理工学部
}

J. Japan Inst. Metals, Vol. 60, No. 11 (1996), pp. 1031-1036

\section{Crystallization Processes of Amorphous Al- and Fe-Base Alloys}

\author{
Hiroshi Fujita*, Takefumi Tsuboi** and Katsuyuki Harada**† \\ *Research Institute for Science and Technology, Kinki University, 3-4-1 Kowakae, Higashiosaka, Osaka 577 \\ **Department of Metallurgy, Faculty of Science and Engineering, Kinki University, 3-4-1 Kowakae, \\ Higashiosaka, Osaka 577
}

\begin{abstract}
An electron microscope study has been carried out on the crystallization processes of amorphous aluminumand iron-base alloys with the following results: 1) The nucleus sizes of both primary crystals are almost constant in a wide temperature range more than $100 \mathrm{~K}$. 2) Lattice constants of both primary crystals are gradually changed until the crystallization is finished, i.e., it increases in the Al-alloy and decreases in the Fe-alloy. 3) The size of primary crystals becomes about $\phi 10 \mathrm{~nm}$ in both alloys after crystallization, and do not grow until the secondary phases are precipitated. 4) They grow further to $\phi 50 \sim 100 \mathrm{~nm}$ at $573 \mathrm{~K}$ in the former specimens and at $973 \mathrm{~K}$ in the latter ones. After that, there is no remarkable change in their size in a temperature range of $100 \sim 150 \mathrm{~K}$ higher than these temperatures.

The results are discussed in terms of the effect of guest elements exhausted from the primary crystals.
\end{abstract}

(Received May 27, 1996)

Keywords: amorphous aluminum-base alloy, amorphous iron-base alloy, crystallization, primary crystal, nucleus size, exhausted guest element, nanoscale grain size

\section{I . 序論}

アモルファス合金はその原子構造に依存する特異な性質を 示すが，最近になってある特種な目的にはアモルファス合金 を結晶化によって超微細結晶粒度の材料とする方がより効果 的であることが分かってきた，ての一つは軟磁化材料(1)であ り，今一つは高強度材料(2)の製作である。この 2 つ目的 とる，結晶粒度を $10 \mathrm{~nm}$ 尺度で制御すると同時に，でされ ば熱的にも安定な組織とすることが必要であるが，そのため には結晶化過程を左右する要因を明らかるとが必要で ある.しかし、アモルファス合金の結晶化過程すら必ずしも 明確にされて和らず，アモルファス化のために添加される元 素の役割についても未だ明らかたされていない。

著者らは, 先にこのアモルファス化について調べた結果,

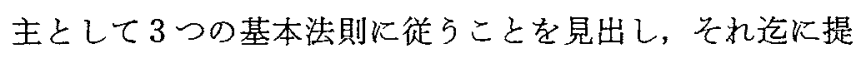
唱されてきた諸因子との関俰をも明らかにした(3). 本研究 は,この基本法則の立場からアェルファス合金の結晶化過程 を再検討することを目的とした。

一方，この結晶化には結晶核の形成が必要であるが，通常

$†$ 近畿大学大学院生(Graduate Student, Kinki University)
結晶核の成長速度が材料の過冷度に極めて敏感なために，そ の機構は勿論のこと，その寸法すら正確に求めることは極め て困難である、既に著者らが発表(3)したように，結晶のアモ ルファス化には物質固有の臨界寸法があるが，ある意味では アモルフ $、$ ス合金の結晶化はこの逆の過程であり，この臨界 寸法に相当するるのが結晶核である可能性が強い，その意味 で，比較的低温で結晶化が起こるばかりか，それらの成長る 抑制されるアモルファス合金の低温に扣ける結晶化は，結晶 核の形成を調べる目的に適していると言える。

以上の観点から, 本研究では $\mathrm{Fe}$ 系执よび $\mathrm{Al}$ 系アモルフ ァス合金を用いて，両者に共通な現象を中心に結晶化過程を 詳細に調べた。

\section{II. 試料および実験方法}

試料として，液体急冷法で作製した at\%で $\mathrm{Fe}_{73.5} \mathrm{Cu}_{1} \mathrm{Nb}_{3}$ $\mathrm{Si}_{13.5} \mathrm{~B}_{9}$ (断面が約 $18 \mu \mathrm{m} \times 5 \mathrm{~mm}$ のリボン)括よび $\mathrm{Al}_{94.5} \mathrm{Ni}_{3.5}$ $\mathrm{Cu}_{1.4} \mathrm{Ce}_{0.6}$ (断面が約 $16 \mu \mathrm{m} \times 0.5 \mathrm{~mm}$ のリボン)のアモルファ ス合金を用いた．使用した Fe系および $\mathrm{Al}$ 系合金ともに加 熱時には極めて酸化し易いために，(Ar+10 vol\% $\left.\mathrm{H}_{2}\right)$ の混 合ガス中であ処理したが，主として $9 \times 10^{-5} \mathrm{~Pa}$ の真空封入 
および水素気流中で $1.8 \mathrm{ks}$ の等時間焼鈍を行い，結晶化と 最大約 $100 \mathrm{~nm}$ 径までの結晶粒の成長過程を調べた。

これら熱処理を施した試料について， Fe 系合金では主と してイオンミリング法で，また $\mathrm{Al}$ 系合金では主として電界 研磨法で薄膜化した後に，それらの結晶化過程を透過型電子 顕微鏡 (以下電顕) JEM-3010 型を用いて，加速電圧 $300 \mathrm{kV}$ で観察した．また，電子回折像より，結晶化传ら格子定数 の変化を同時涀定した。この際，使用したイオンミリング 法では Ar ガスを用いて電王 $10 \mathrm{kV} て ゙$ 試料を回転させながら 両面よりイオン照射を行い，電解研磨法では液として約 240

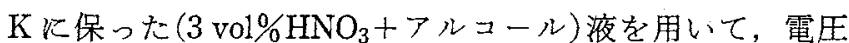
$10 \mathrm{~V}$, 電流 $40 \mathrm{~mA}$ で行った。

\section{III. 実 験 結 果}

\section{1. アモルファス合金の結晶化とその後の結晶粒成長}

(1) Fe 系アモルファス合金

Fe系合金では，真空封入処理により603 Kから $1173 \mathrm{~K}$ までの種々の温度で $1.8 \mathrm{ks} の$ 等時間焼鈍を行った。この際， 本研究では，試料方位を広範に変化させて観察を行い，後述 のように各結晶粒のコントラストが大きく変化した多くの写 真から個々の結晶粒执よび結晶化の度合を判定した．Fig. 1 は，このょらにして得られた組織の変化を示す一例でこれ らの写真から次のことが分かる。

まず，693 K までの熱処理では，ブラッグ反射による像の コントラストは現れず, $703 \mathrm{~K}$ で所々に約 $6 \mathrm{~nm}$ 径の bcc の $\mathrm{Fe}$ 初晶が形成される。 $743 \mathrm{~K}$ では 6 $7 \mathrm{~nm}$ 径の $\mathrm{Fe}$ 初晶粒 の数が増加するが，結晶粒度は $703 \mathrm{~K}$ ののに比べて殆ど 変化していない. $763 \mathrm{~K}$ になると，約 $10 \mathrm{~nm}$ 径の結晶粒が
多く形成されるが，結晶粒の最小径は依然 $6 \mathrm{~nm}$ 径であった。

Fig. 2 は $803 \mathrm{~K}$ で武料全体が結晶化したと考兄られるもの であるが，結晶粒の平均の大きさは約 $10 \mathrm{~nm}$ 径から殆ど変 化せず，また結晶粒の最小径は番号 1〜6で示したように6 $\mathrm{nm}$ 径であることが分かる. Fig. 2 の (a)と(b)は試料方位を 互に $10^{\circ}$ 変化させて撮影したもので，図中の矢印は試料の同 一䈯所を示している，また結晶化の度合の判定には，試料を 電子線に対して $10^{\circ}$ 傾けて全方位に回転させ，元の間に Fig. 2 の (a)と(b)のようにブラッグ条件の変化によってコン トラストが変化した結晶粒の多くの写真を撮影して互い娷
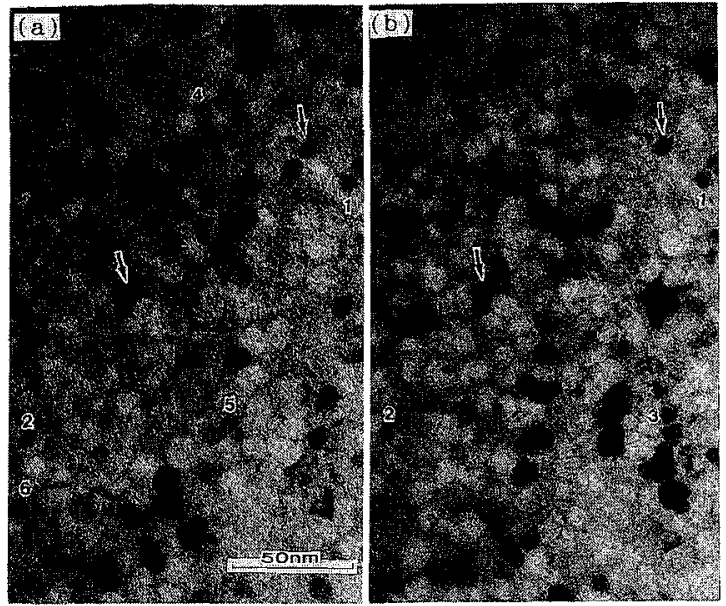

Fig. 2 Contrast change of individual crystals in the amor phous Fe-alloy annealed at $803 \mathrm{~K}$ by changing specimen orientation.

Micrograph (b) was taken after the specimen orientation was changed to $10^{\circ}$ from that in micrograph (a). In micrographs (a) and (b) , arrows and figures show the same grains and primary crystals of the minimum size respectively.

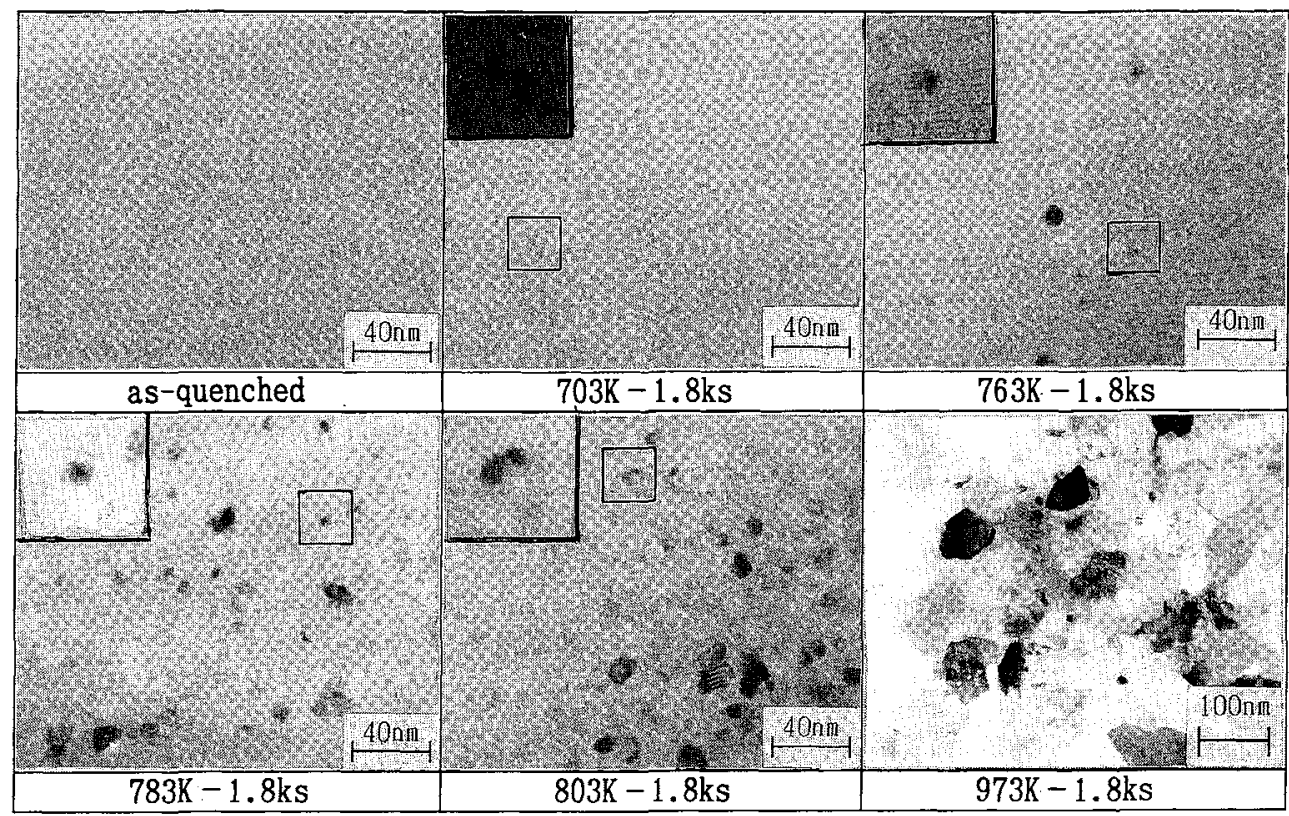

Fig. 1 Crystallization process of the amorphous Fe alloy. An enlarged micrograph at the upper left corner of each micrograph shows the minimum size of the primary crystals in a framed part. 
ね合わせ，その時に鮮明に現れた結晶粒の数とその分布から 決定した。

さらに，この結晶化終了後に $923 \mathrm{~K}$ をで温度を上昇させ たが，結晶粒径は殆ど変化せずに約 $10 \mathrm{nmであった。その}$ 後, $973 \mathrm{~K} に$ で温度を上昇させると， Fe 結晶粒は顕著な 成長を起こすと同時に，Fig. 1 火見られるように $\mathrm{Fe}_{3} \mathrm{~B}$ 和よ び $\mathrm{Fe}_{23} \mathrm{~B}_{6}$ の析出(1)が起こり，殆どの結晶粒は $50 \mathrm{~nm}$ 径を越 える大きさとなる。その後は，さらにそれより $200 \mathrm{~K}$ 高い $1173 \mathrm{~K}$ まで盜度を高めても結晶粒度に大さな変化はなかっ た.

Fig. 3 は，以上の結果を図示したものであり，その中で 結晶粒径の変化が少ない $743 \sim 823 \mathrm{~K}$ の温度領域での結晶粒 度分布をFig. 4 K示した。この図で注目すべきことは，最 小粒径はこの温度範囲では約 $6 \mathrm{~nm}$ 之一定で，この寸法以下 の結晶粒は確認されなかったことである。したがってこの 合金系比护る bcc の Fe 初晶の臨界寸法は $6 \mathrm{~nm}$ 径であり, これがこの結晶の結晶核化相当すると考えられる。

\section{(2) $\mathrm{Al}$ 系合金}

この合金では，真空封入和よび水素気流中処理により， $300 \mathrm{~K}$ から $673 \mathrm{~K}$ までの種々の温度で $1.8 \mathrm{ks}$ の等時間焼鈍 を行い，Fig.5の結果を得た。これらの結晶粒度に関する 結果は，上述の 2 種類の処理で大差はなかった。

この Al 系合金は，材料強化の目的でアモルファス合金中 にあらかじめ約 $5 \mathrm{~nm}$ 径の $\mathrm{fcc} の \mathrm{Al}$ 初晶が点在する状態に 処理されている(2).この試料の熱処理では， $373 \mathrm{~K}$ で新たに 結晶粒径が約 $5 \mathrm{~nm} の \mathrm{fcc} の \mathrm{Al}$ 結晶粒が現れ始め, 結晶化 温度は $373 \mathrm{~K}$ であることが分かる。さらに温度を上げると， $413 \mathrm{~K}$ では約 $10 \mathrm{~nm}$ 径の結晶粒が確認できるようになり, $433 \mathrm{~K}$ で結晶粒の数はさらに増大して試料全体を占める。こ の結晶粒度は，さらに温度を上げても約 $500 \mathrm{~K}$ までは変わ らなかった。この際, この温度範囲での結晶の最小粒径は

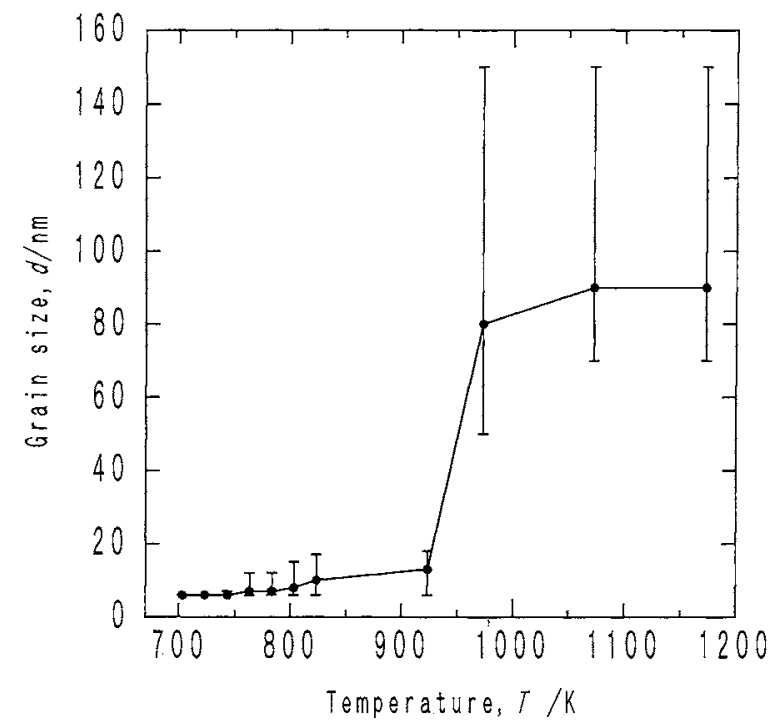

Fig. 3 Grain size of the primary crystals in the amorphous Fealloy as a function of annealing temperatures.

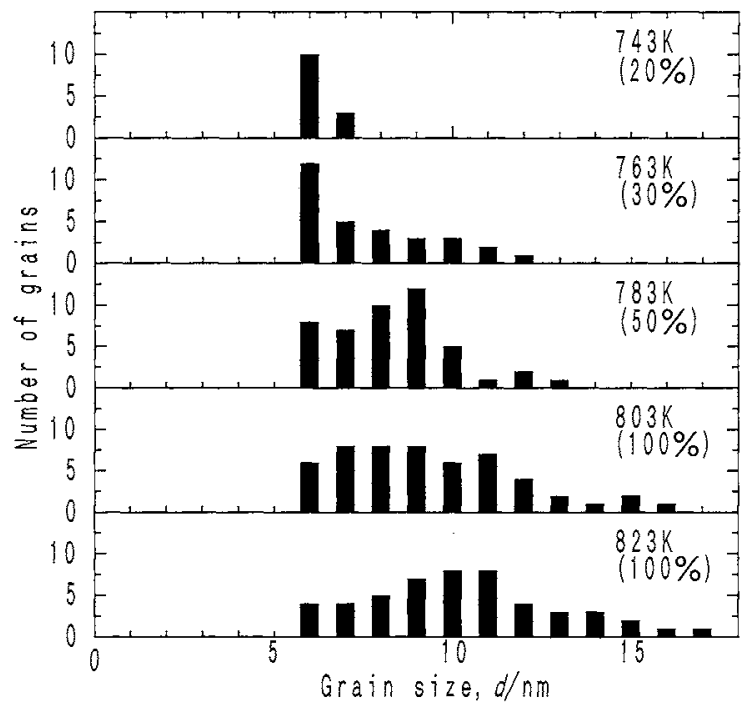

Fig. 4 Distribution of grain size of the primary crystals in the amorphous $\mathrm{Fe}$-alloy as a function of annealing temperatures. Each number in parenthesis shows a volume fraction of crystallized regions.

$\mathrm{Fe}$ 系合金と同様隹一定で，いずれる約 $5 \mathrm{~nm}$ 径であった。 焼鈍温度をさらに $573 \mathrm{~K}$ に上げると， $\mathrm{Al}$ 結晶粒は $50 \mathrm{~nm}$ 径 以上のものへと成長し，同時に $\mathrm{Al}_{3} \mathrm{Ni}$ 特よび $\mathrm{Al}_{3} \mathrm{Ce} の$ 析 出 ${ }^{(2)}$ が䜑められる。 その後に，これより $100 \mathrm{~K}$ 高い $673 \mathrm{~K}$ の焼鈍を行ったが，これも $\mathrm{Fe}$ 合金と同様に結晶粒度には大 きな変化は認められなかったＦig.6はこの関係を図示し たもので，(a)約 $500 \mathrm{~K}$ 亲の゙初晶の最小粒径はすべて約 5 $\mathrm{nm}$ であること, (b) 平均粒径もこの間は約 $10 \mathrm{~nm}$ と注ぼ一 定で, 結晶粒数のみ增大すること, さらに(c)平均粒径は $573 \mathrm{~K}$ で急速に成長した後は, 少なくとも $673 \mathrm{~K}$ ま゙は大 きな変化のないこと，が分かる。

\section{2. 結晶化に伴う格子定数の変化}

上述のように， $\mathrm{Fe}$ 系和よび $\mathrm{Al}$ 系合金のいずれに怙いて も, 初晶の組成から考えて結晶化の間には局所的な元素濃度 の変化が起こっていると考えられる，そこで，電子回折法に より結晶化中の格子定数の変化を測定した.

(1) Fe 系アモルファス合金

Fig. 7 は Fe系アモルフォス合金中でのbccの Fe 結晶の 析出に伴う格子定数の変化を示したものである。まず，熱処 理温度が $693 \mathrm{~K}$ まではアモルファス構造であるが, $6 \mathrm{~nm}$ 径 の bcc $の \mathrm{Fe}$ 初晶が点在する $703 \mathrm{~K}$ では強度の弱い $\{110\}$ 回 折リングが確認でき，その時の格子定数は $0.292 \mathrm{~nm}$ であっ た、その後， $743 \mathrm{~K}$ から結晶粒が試料全体を覆う803 K での熱処理では，結晶化に伴って格子定数は $0.287 \mathrm{~nm}$ にま でほぼ直線的に減少した。この格子定数の変化から, 結晶化 温度以上では bcc の $\mathrm{Fe}$ 結晶の生成に伴って, その中に固溶 している Feよりも原子半径が大きい元素か，または侵入型 添加元素が排出されていることが分かる. 


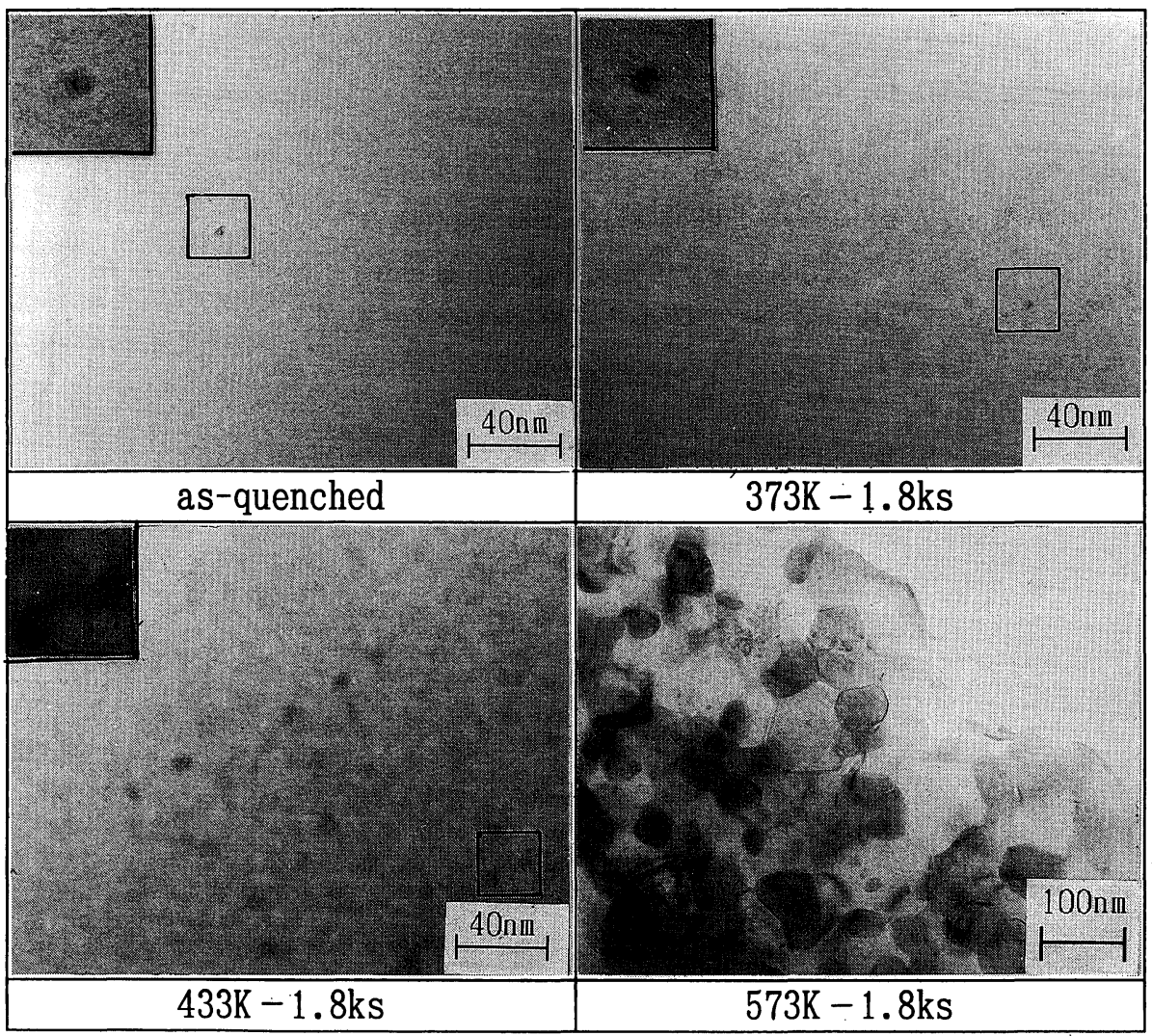

Fig. 5 Crystallization process of the amorphous Al-alloy. Enlarged micrographs show the minimum size of the primary crystals at each annealing temperature.

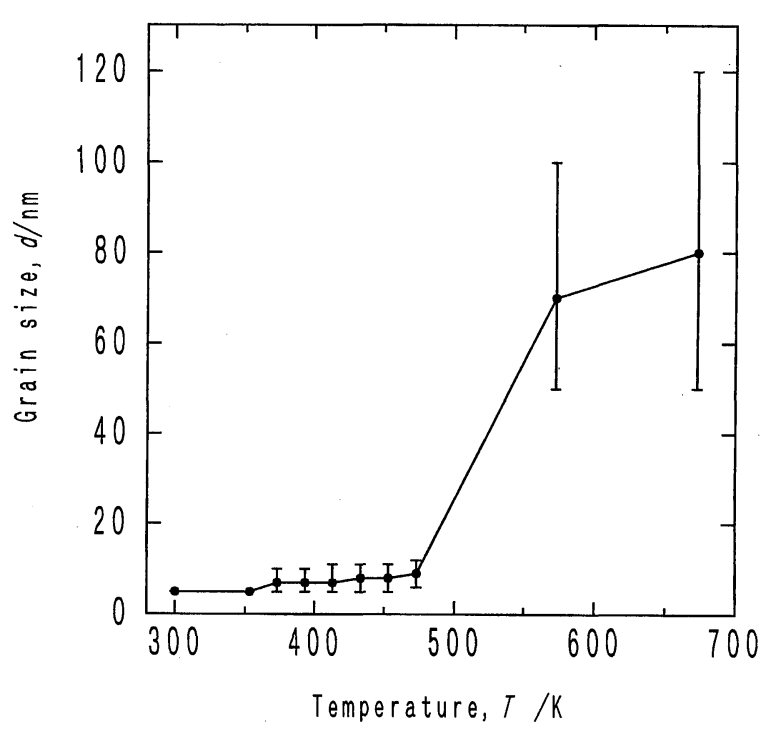

Fig. 6 Grain size of the primary crystals in the amorphous Alalloy as a function of annealing temperatures.

\section{(2) $\mathrm{Al}$ 系アモルファス合金}

電子回折像では，最初に $\{111\}$ 回折リングが結晶粒の数が 増加し始める $393 \mathrm{~K}$ で確認され，その時の格子定数は 0.401 $\mathrm{nm}$ であった．その後, $413 \mathrm{~K}$ から結晶粒が試料全体を覆う $433 \mathrm{~K}$ までの間に格子定数は Fig. 8 のように $0.404 \mathrm{~nm}$ にま で増加した．このことより，この場合には $\mathrm{Al}$ より小さい元

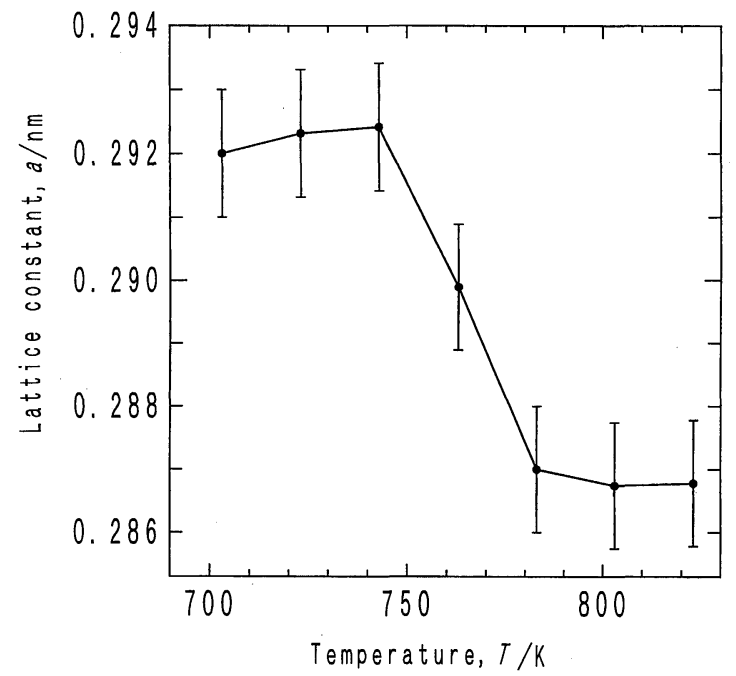

Fig. 7 Lattice constant of the primary crystals in the amorphous Fe-alloy as a function of annealing temperatures.

素が結晶化の進行に伴い排出され, $\mathrm{Al}$ の格子定数は増加し たと結論される。

\section{N. 考察}

本実験では， $\mathrm{Fe}$ 系拉よび $\mathrm{Al}$ 系アモルファス合金の結晶 化について調べた結果，次のことが両合金について共通であ 


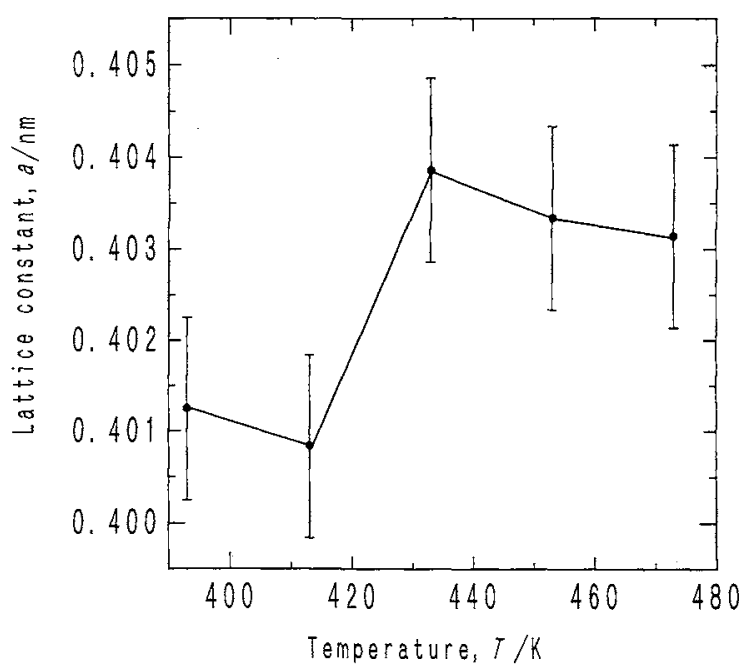

Fig. 8 Lattice constant of the primary crystals in the amorphous Al-alloy as a function of annealing temperatures.

ることが分かった。

\section{1. 初晶の結晶核と熱処理温度}

$\mathrm{Fe}$ 系アモルファス合金では，約 $740 \mathrm{~K}$ の等時間焼鈍で $\mathrm{bcc} の \mathrm{Fe}$ 初晶が形成され始め, 加熱温度の上昇ととも初 晶の数以増加して，約 $803 \mathrm{~K}$ で試料全体が結晶化する。 一 方，A1 合金の結晶化は $373 \mathrm{~K}$ から始まり，433 K で完了す る。この間，いずれの合金でも初晶の核に相当する最小粒径 は変わらず，Al系では約 $5 \mathrm{~nm}$ ，鉄系合金では約 $6 \mathrm{~nm}$ と子 るに一定であり，結晶粒の数だけが増加する。しかも，新し く現れる各結晶粒は Fig. 1 拉よび Fig. 5 に見られるように 互い烛立に形成され，その後の互い接し合って結晶化の 完成与る時点で両合金ともに約 $10 \mathrm{~nm}$ 径となり，僅か炕成 長する。，その後性，さらに䄪 $100 \mathrm{~K}$ の温度上昇を行っても 結晶粒度の大きな変化は認められない。

以上の結果から， $\mathrm{Fe}$ 系合金の場合には $6 \mathrm{~nm}$ 径が， $\mathrm{Al}$ 系 合金の場合には $5 \mathrm{~nm}$ 径が去れぞれ初晶の結晶核寸法之考光 られる。さらに，これらの結晶核寸法は焼鈍温度が的 200 Kも変化したkも拘和らず殆ど変化しなかった。このこと は，著者らが既に発表した(4)ように，アモルファス相い結晶 㖶移を含む相変態には電子構造の変化が必要と考光ると，そ れ比要する活性化エネルギーは一般似数百 $\mathrm{kJ} / \mathrm{mol}$ (数 $\mathrm{eV}$ ) なりこれに対して上述の焼鈍に拊ける熱エネルギー $k \mathrm{~T}(k$ : ボルッマン定数, T: 絶対温度) 以桁遧い炕小く, $T=1000 \mathrm{~K} て ゙ 10 \mathrm{~kJ} / \mathrm{mol}$ 以下であることを考觉ると理解で きる。

\section{2. 初晶の成長に及ぼす添加元素の影響}

使用した両合金では，Fig. 3 と 4 亿見られるように，初晶 の核寸法は一定で，その結晶粒度は焼鈍温度の上昇とともに 結晶化の完了する約 $10 \mathrm{~nm}$ 径までゆっくりと增加する．と

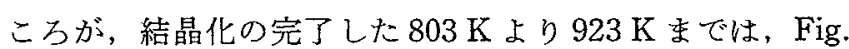
3 火示したように個々の結晶粒は殆ど成長しない。この現象
は添加元素の種類と密接な関保があると考えられる。

Fig. 7 およびFig. 8 亿示したように，両合金ともに初晶 の格子定数は結晶化の開始より完了するまで变化をつづけ, アモルファス地含まれていた添加元素がこれら初晶より排 出されていることが分かる．これら添加元素の多くは，母相 のアモルファス化槣与して拉り，筆者らが既炕発表してい る(3)上うに, アモルファス化のためには構成原子の1つは 複数の結合モードを持つと同時に，Table 1 から分かるよう に，構成原子間ではとの電子構造の違いが大きい注ど(周期 律表で互い炕離机る性ど)アモルフ、ス化が容易となる。

これらの元素は， $\mathrm{Fe}$ 采の場合火は結晶化によって格子定 数の減少していることから, Vegard の法則より Fe 原子ょ り大きい $\mathrm{Nb}$ 原子，侵入型である $\mathrm{B}$ ，むた性固溶限の少ない $\mathrm{Cu}$ が，また同じく $\mathrm{Al}$ 系合金では格子定数の增加から主々 してNi 扣よびCuが排出されていることが分かる。机た， $\mathrm{Al}$ 系合金の場合汇性，原子半径の大きな $\mathrm{Ce}$ が初晶の形成 とともにその界面偏析する可能性が強い，これら排出され た元素の多くは，最初上り初晶の結晶化を阻害しているが， さらに排出された添加元素間でも Table 1 のごとく互い周 期律表上の位置は離れている。したがって，これら初晶汇排 出された元素集団は互いに結晶化を妨げる作用が強いばかり か，その偏析層の薄いことからも結晶化怯難しい(4). その結 果, 各初晶はこれら排出された添加元素の層汇包采れ，その 層が後述の第 2 相として析出するまでは初晶の成長を妨げ ることになる。前述の Fig. 1 と Fig. 5 では，初晶は殆ど成 長せず沈の数をのみ増加させる結果は，このことを裏付け るものと考光られる。

ところで，この初晶を包む添加元素を多く含む界面層は， 母相元素に対して電気陰性度の差の大きいはど母相の電子構 造を大きく变化させる(5)ものと考克られる． $\mathrm{Al}$ 系合金では $\mathrm{Cu}, \mathrm{Ni}$ と $\mathrm{Ce}$ 原子が，また $\mathrm{Fe}$ 系合金では $\mathrm{Nb}$ と $\mathrm{B}$ 原子がそ れ飞相当して脆性を促進すると考兄られるが，特に $\mathrm{Al}$ 系合 金での Ce は酸化し易いためにその傾向を強めると考光られ る。したがって，両アモルファス合金とも火，結晶化と同時 飞界面の脆化が促進され，これら排出元素が第 2 相として 析出するまでは脆化の度合は著しくなると考光られる。

\section{3. 熱的に安定な結晶粒径約 $100 \mathrm{~nm}$ への成長}

上述の上らに、A $\mathrm{A}$ 系扣よび $\mathrm{Fe}$ 系合金の初晶は, 添加元 素の影響によって結晶化の開始よりさらに約 $200 \mathrm{~K}$ も高い

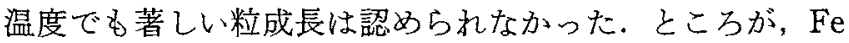
系合金では，973 Kより， $\mathrm{Al}$ 系合金では $573 \mathrm{~K}$ より，とも に結晶粒径は約 $10 \mathrm{~nm}$ 上り 50 〜 $100 \mathrm{~nm}$ 一と急速に成長す る。この粒径が約 $100 \mathrm{~nm}$ に成長した試料を観察して見る 之, 各母相粒子の間炕結晶の対称性の悪い第 2 相が Fig. 1 および Fig. 5 のように析出してくる。すなわち，この段階 では, 前述の初晶を取り巻く脆化層は第 2 相として結晶化 し，50 100 nm の間隔で形成される.この第 2 相は $\mathrm{Al}$ 系 では $\mathrm{Al}_{3} \mathrm{Ni}$ 㧊よび $\mathrm{Al}_{3} \mathrm{Ce}$ 相(2) として, $\mathrm{Fe}$ 系の場合には $\mathrm{Fe}_{3} \mathrm{~B}$ 
Table 1 Relationships between different constituent elements of amorphous Fe- and Al-base alloys in the periodic table. In the table, open circles and triangles show elements involving in the Al-and the Fe-base alloys respectively. Difficulity of crystallization increases with increasing separation among different constituent elements in the periodic table.

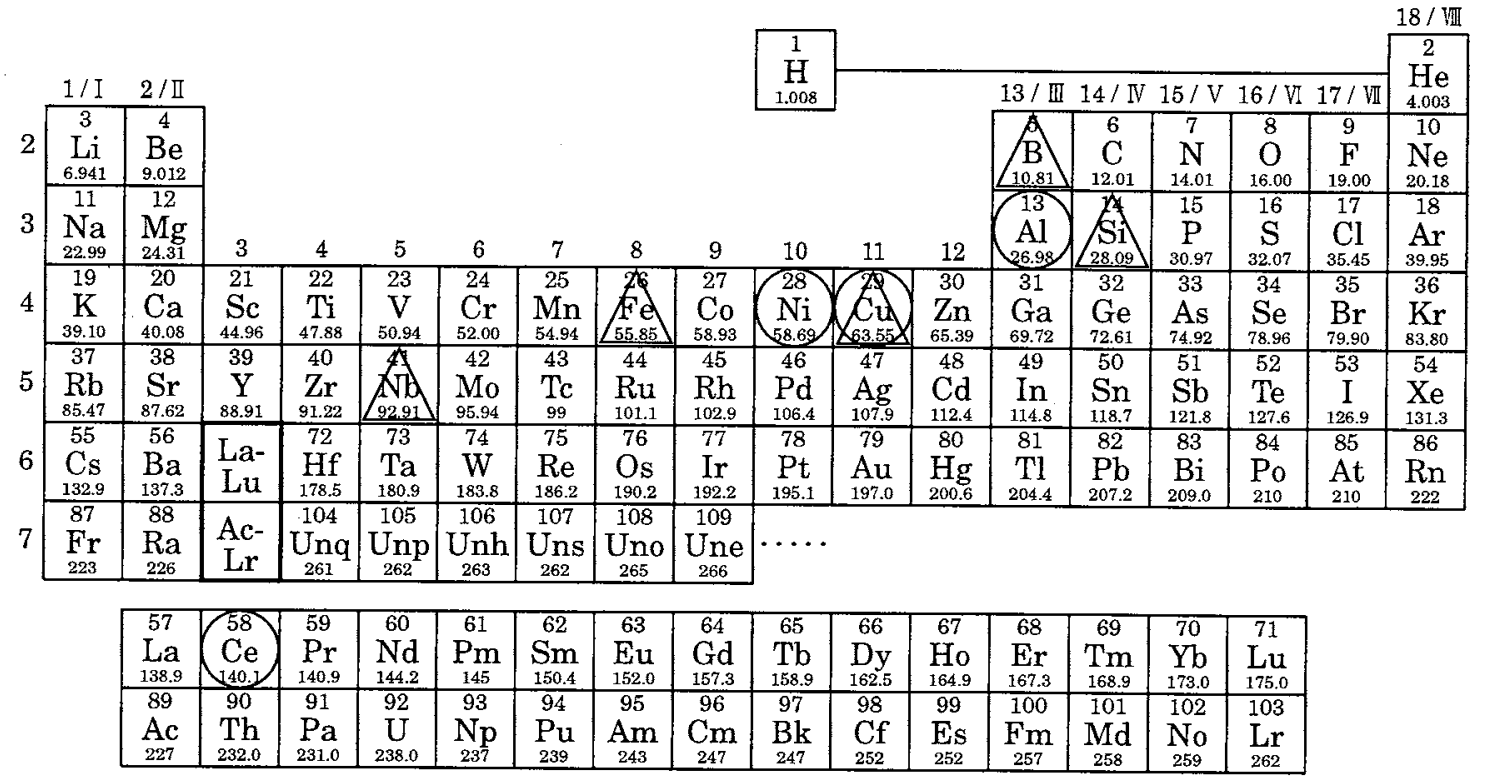

および $\mathrm{Fe}_{3} \mathrm{~B}_{6}$ 相の析出物(1)を形成することが分かっている。 その結果，母相結晶粒はこれら第 2 相の間隔と同程度まて 成長できることになる。これら第 2 相は $0.7 \mathrm{~T}_{\mathrm{m}}$ 近くの温度 でも十分熱的に安定なために, 上述の成長後は第 2 相の析 出温度より少なくとも $200 \mathrm{~K}$ 程度高い温度まで憢的炕安 定であり，これらの粒子で成長を妨げられている母相粒子の 粒度も变わらなかったものと考光られる。この結晶粒度 $100 \mathrm{~nm}$ の材料は引張強度が著しく高くなると予想され(6)(7), しかも熱的に安定なために，今後実用的に重要になることが 予測される。この際, 既述の第一段階で形成される初晶界面

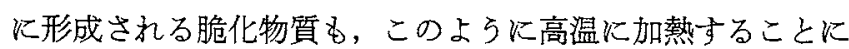
よって第 2 相として結晶粒の微細化化利用することが可能 となるであるう。

\section{V. 結論}

本研究で怯， $\mathrm{Al}$ 系扔よび $\mathrm{Fe}$ 系アモルファス合金につい て $1.8 \mathrm{ks}$ の等時間焼鈍を行い，その結晶化過程を調べた結 果，次のことが明らかとなった。

(1) $\mathrm{Al}$ 系执よび $\mathrm{Fe}$ 系アモルファス合金の結晶化温度は

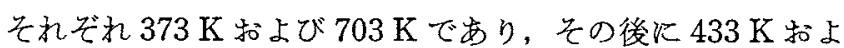
び $803 \mathrm{~K}$ で泀济試料全体が結晶化する. この時, 結晶化完 了直後の結晶粒度は両合金ともに約 $10 \mathrm{~nm}$ であった.

（2）この可成り広い温度範囲炕も拘わらず，この間に形成 されるそれぞれの結晶核に相当する初晶の最小寸法は両合金 そもに一定で, $\mathrm{Al}$ 系合金では約 $5 \mathrm{~nm}$ 径, $\mathrm{Fe}$ 系合金では約 $6 \mathrm{~nm}$ 径であった.さらに，この温度範囲で性前者の格子定 数は結晶化とともに増加し，後者のそれは減少した。

(3) $\mathrm{Al}$ 系合金では $433 \mathrm{~K}$ よりさらに $500 \mathrm{~K}$ まで， Fe系
合金では $803 \mathrm{~K}$ より $923 \mathrm{~K}$ までは結晶粒度に変化はなく， ともに約 $10 \mathrm{~nm}$ であった。

(4) A1 系合金では $573 \mathrm{~K}$ で第 2 相の析出とともに結晶粒 は 50 100 nm 径成長した後, 少なくとも，673 $\mathrm{K}$ までは 再び結晶粒度の变化は殆どなかった. $\mathrm{Fe}$ 系合金でも同じく， $973 \mathrm{~K}$ で第 2 相の析出々とも $50 \mathrm{~nm}$ 以上の結晶粒度に成 長した後, 少なくとも $1173 \mathrm{~K}$ すでは結晶粒の成長は認めら れなかった。

これらの諸結果次つて，各初晶とそれより排出される添 加元素との相互作用の立場から考察を加えた。

本研究に使用した $\mathrm{Al}$ 系アモルファス合金は東北大学・金 属材料研究所井上明久教授より,また $\mathrm{Fe}$ 系アモルファス 合金恃日立金属侏荒川俊介和上び戸田忠俊両氏の提供によ るものでありここに衰心よりこれらの方々のご厚情に感謝 申し上げる次第です，また，この研究の一部を協力願った近 畿大学・理工学部学生 春田博信叔よび山本和紀両氏謝意 を表します。

\section{文献}

（1）吉沢克化, 山内清隆：日本金属学会会報，28(1989)，302；日 本金属学会誌, 55(1991), 588 .

(2) A. Inoue, K. Nakazato, Y. Kawamura and T. Masumoto: Mater. Sci. Eng., A179/A180(1994), 654.

( 3 ) H. Fujita: Proc. New Mater, '88, 2nd Int. New Mater. Conf., Osaka, (1990), 523; Mater. Trans., JIM, 31(1990), 523.

(4) H. Fujita: Mater. Trans., JIM, 35(1994), 563.

(5) 例忘ば, C. L. Briant and R. P. Messmer: Phil. Mag., B42 (1980), 569 .

(6) S. Miyazaki, K. Shibata and H. Fujita: Acta Metall., 27 (1978), 855; H. Fujita and S. Miyazaki: Acta Metall., 26(1978), 1273.

（7）藤田廣志：金属, AGNE, (1987), 5 . 